\title{
Rubrapterus bavius from north-eastern Bulgaria and new data on its conservation status in Romania
}

\author{
László Rákosy \& Michael WeIDLICH
}

\begin{abstract}
Summary: The first specimen of Rubrapterus bavius from north-eastern Bulgaria was collected on the 04.05.2013, near Balik, approximately $30 \mathrm{~km}$ south from the nearest population from south-eastern Romania. Based on a review of the literature and input from personal research, the authors discuss the situation of the species from a biological, phylogenetic and conservation point of view.
\end{abstract}

Rezumat: Primul exemplar de Rubrapterus bavius din nord-estul Bulgariei a fost colectat la 04.05.2013 din apropierea localităţii Balik, la aproximativ $30 \mathrm{~km}$ sud de localitățile cele mai apropiate din sud-estul României din care a fost semnalată această specie. Pe baza informaţiilor din literatură şi a celor personale, autorii prezintă situaţia speciei sub aspect biologic, filogenetic şi conservativ.

Key words: Rubrapterus, (Pseudophilotes) bavius, Bulgaria, Romania, Dobrogea, ecology, conservation

\section{Introduction}

The Bavius Blue has been frequently assigned either to the genus Pseudophilotes or Scolitantides. Molecular analyses (UGELVIG et al. 2011) have, however, revealed strong genetic divergence between Pseudophilotes bavius and the remainder of the genus, the decision to assign $P$. bavius to the monotypic genus Rubrapterus KorshUNOv, 1987 thus appears justified (Kolev 2017).

In Romania, Rubrapterus bavius (Bavius Blue) has been the subject of numerous publications since 1980 (Szabó 1982, VICOL 1983, KöNIG 1988, 1992, JutZeler et al. 1993, CRIŞAN et al. 2011, 2014, DiNCĂ et al. 2011, RÁKOSY 1983, 1998a,b, 2013, RÁKosy and SzÉKelY 1996, SzÉKeLY 2016). The Transylvanian populations have been thereby shown to belong to R. bavius hungarica (Diószeghy 1913), while those from Dobrogea have been attributed, without comparative studies, to $R$. bavius egea. In Transylvania, $R$. bavius hungarica occurs in several small and isolated populations in the plains and low altitude hillsides of the Transylvanian plateau (Fig. 1, 2). Although the investigations into the distribution of this subspecies have been intensified over the last 15 years, many of the Transylvanian populations and colonies are likely to have remained undiscovered. The larvae of this butterfly live in the flower heads of the Nodding Sage, Salvia nutans, a plant which prefers loamy- sand or calcareous soils in areas with landslides or patches of bare soil, where competition from other plant species is minimal (Fig. 2). In captivity the larvae feed also on other species of Salvia, especially S. pratensis (KöNIG 1988, 1992, JutZeler et al. 1993, HAGEN 1996). The facultative interaction between $R$. bavius larvae and their ant partners, as well as host plant selection in the field and related conservation perspectives, were studied by NÉMET et al. (2016). The imagos do not travel large distances, their mean daily flight distance reaching only about $30 \mathrm{~m}$ (CRIŞAN et al. 2014). In their lifetime most $R$. bavius individuals do not fly over distances larger than $100 \mathrm{~m}$ (CRIŞAN et al. 2014). Aided by air currents, some individuals can, in exceptional cases, travel between 1 and $3 \mathrm{~km}$ during their short (3-9 days) life span. The current land configuration has imposed a strongly insular character upon the optimal habitats of $R$. bavius hungarica, which is accentuated by the low mobility of the imagos. In the last years several studies regarding the biology, ecology and conservation of the Transylvanian populations of $R$. bavius hungarica have been published (CRIŞAN et al. 2011, 2014).The size of the populations varies strongly between years. In favourable years 500 to over 800 individuals could be recorded at Suatu and Bărăi (Cluj, Transylvania) (Fig. 2, 3, 4). Similarly, in 2012, in approximately two hours, over 30 individuals could be observed at Gura Dobrogei (south-eastern Romania) (Fig. 5, 6). After one or two abundant years, the populations can decline to just a few individuals, occasionally giving the impression that the population has gone extinct. After five to seven years, the population size rises 


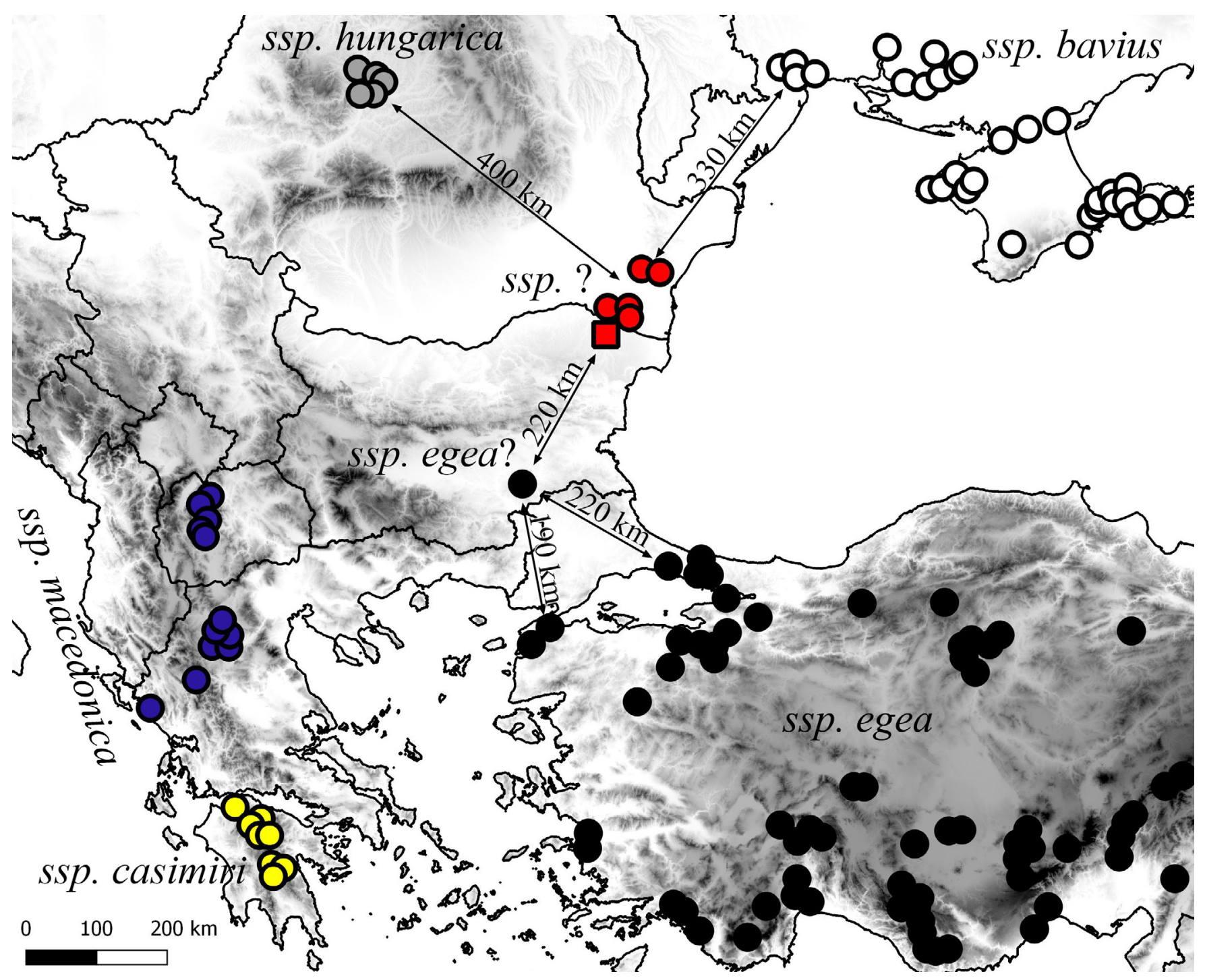

Fig. 1. Western distribution of Rubrapterus bavius. Red square - a new record from north-eastern Bulgaria. General distribution after Dincă et al. (2011); Hesselbarth et al. (1995); Jutzeler et al. (1993); Kolev (2017); Pamperis (2009); Rákosy (2013); Székely (2008, 2016); Tshikolovets (2011).

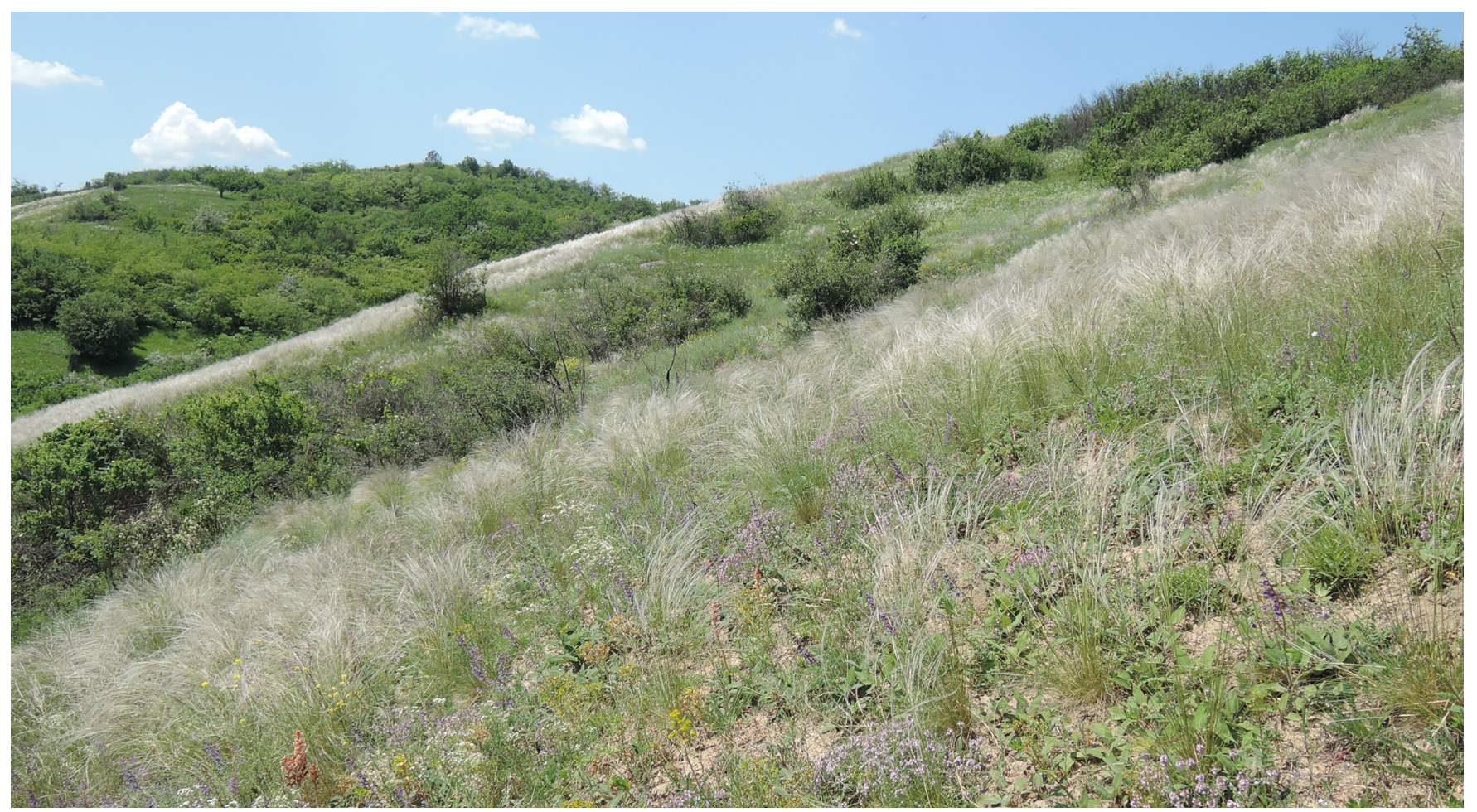

Fig. 2. Habitat of Rubrapterus bavius hungarica from Transilvania, 24.05.2014, Bărăi, Cluj County (Photo: L. Rákosy). 


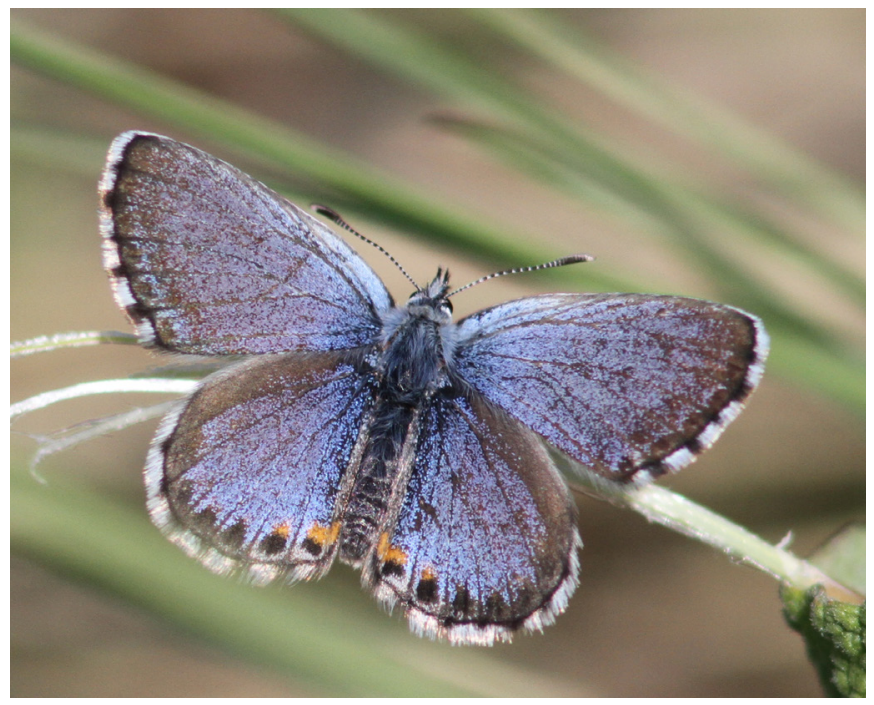

Fig. 3. Male of Rubrapterus bavius hungarica, Bărăi, Cluj County, 26.04.2015 (Photo: L. Rákosy).

again. The factors which determine such fluctuations in population size remain currently unknown.

Little is also known about the biology and ecology of the $R$. bavius populations from Dobrogea. The published data offers only information on the few localities from which the species has been reported, with details regarding only its abundance and its flight period (SzÉKelY 1994, RÁKosY and SzÉKely 1996, SzÉKelY 2016, DincĂ and VILA 2008). DincĂ et al. (2011) provide some theoretical comments regarding the conservation of the $R$. bavius populations from Dobrogea.

Several populations are known from the central and southern part of Dobrogea, some lying very close to the border with Bulgaria (Fig. 1). It appears therefore likely that the species should also occur in Bulgaria, in areas adjacent to those from which the species has been recorded in Romania. This has been in fact the assumption since $R$. bavius has been first recorded in Dobrogea (SZÉKELY 1994, RÁKosY and SZÉKelY 1996). Despite investigations conducted by the Bulgarian lepidopterists, the presence of this species in Bulgaria could not be confirmed for a long time (pers. com S. BeshKov 2012-2013, Kolev 2013). Its absence in the north-eastern part of Bulgaria is even more puzzling, as the habitats from Canaraua Fetei (Dumbrăveni Forest) and Șipote (Fig. 7), located close to the border, extend into the Bulgarian territory. The habitat is currently only partially fragmented by the agricultural practices in Bulgaria. While the agricultural activities of the last 100 years have fragmented and isolated the species' habitat, it is unlikely that small populations, similar to those found in Transylvania or Dobrogea, could not have survived in the remaining habitat fragments. The geographic isolation of the taxon appears also unlikely. This view is supported by the lack of ecological barriers between the habitats in south-eastern Romania (Dobrogea) and those in Bulgaria. However, until recently the search for $R$. bavius in suitable habitats along the border to Romania has remained fruitless.

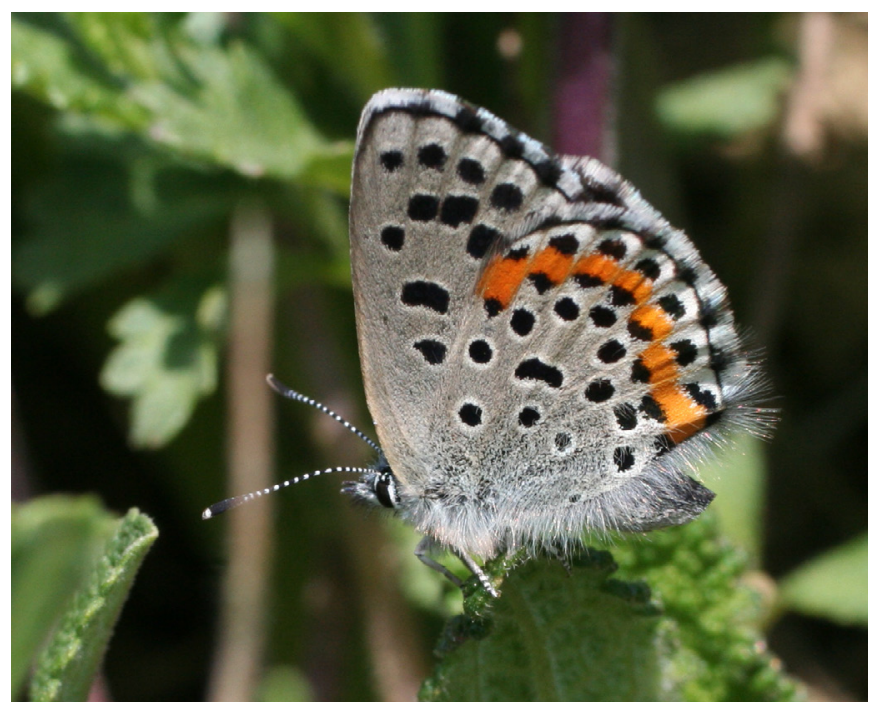

Fig. 4. Female of Rubrapterus bavius hungarica, Suatu, Cluj County, 25.04.2010 (Photo: L. Rákosy).

\section{Discussion}

The occurrence of $R$. bavius in the north-eastern part of Bulgaria was first confirmed by M. WeIDLICH, who on the 04.05.2013, collected a male R. bavius (Fig. $9,10)$ one km south-east of Balik (Dobritsch, Silistra district) at an altitude of $110 \mathrm{~m}$ (Fig. 8). This locality lies only $32 \mathrm{~km}$ from Băneasa (Canaraua Fetii) and $39 \mathrm{~km}$ from Sipote (Fig. 6), the closest Romanian populations. The Suha River has cut into the Sarmatian limestone a gorge with vertical cliffs, 40-50-meters high. The upper parts of the gorge are covered by mixed deciduous forests with Quercus cerris, Q. pubescens, Carpinus orientalis, Fraxinus ornus and xerothermic shrubs. Open areas are characterized by herbaceous, xerothermic vegetation, which has, however, often been replaced by ruderal vegetation or Robinia pseudacacia plantations. Seminatural and natural areas are thereby surrounded by abandoned or extensive agricultural lands. The Suha Reka valley has been included among the Prime Butterfly Areas of Bulgaria, due to the occurrence of the country's most vigorous population of Euphydryas maturna, as well as of other rare Lepidoptera species (ABADJIEV and BeSHKOv 2007). The high number of rare plant and bird species has led to its inclusion into the Natura2000 network (the site covers 62481 ha).

The gorge system from the Suha Reka valley is a continuation of the Canaraua Fetei (Băneasa) gorge from Romania and the presence of $R$. bavius in this habitat is therefore not unexpected (ABADJIEV and BESHKov 2007). In an attempt to find the larval foodplant of $R$. bavius, M. WeIDLICH could only find Salvia pratensis in the investigated area.

Recently, Kolev (2017) has published, under the name Rubrapterus bavius, a record of the species from south-eastern Bulgaria, approximately $300 \mathrm{~km}$ south of the populations known from the border between Romania and Bulgaria. The habitat described by Kolev, the Mediterranean climate, the late flight period and 


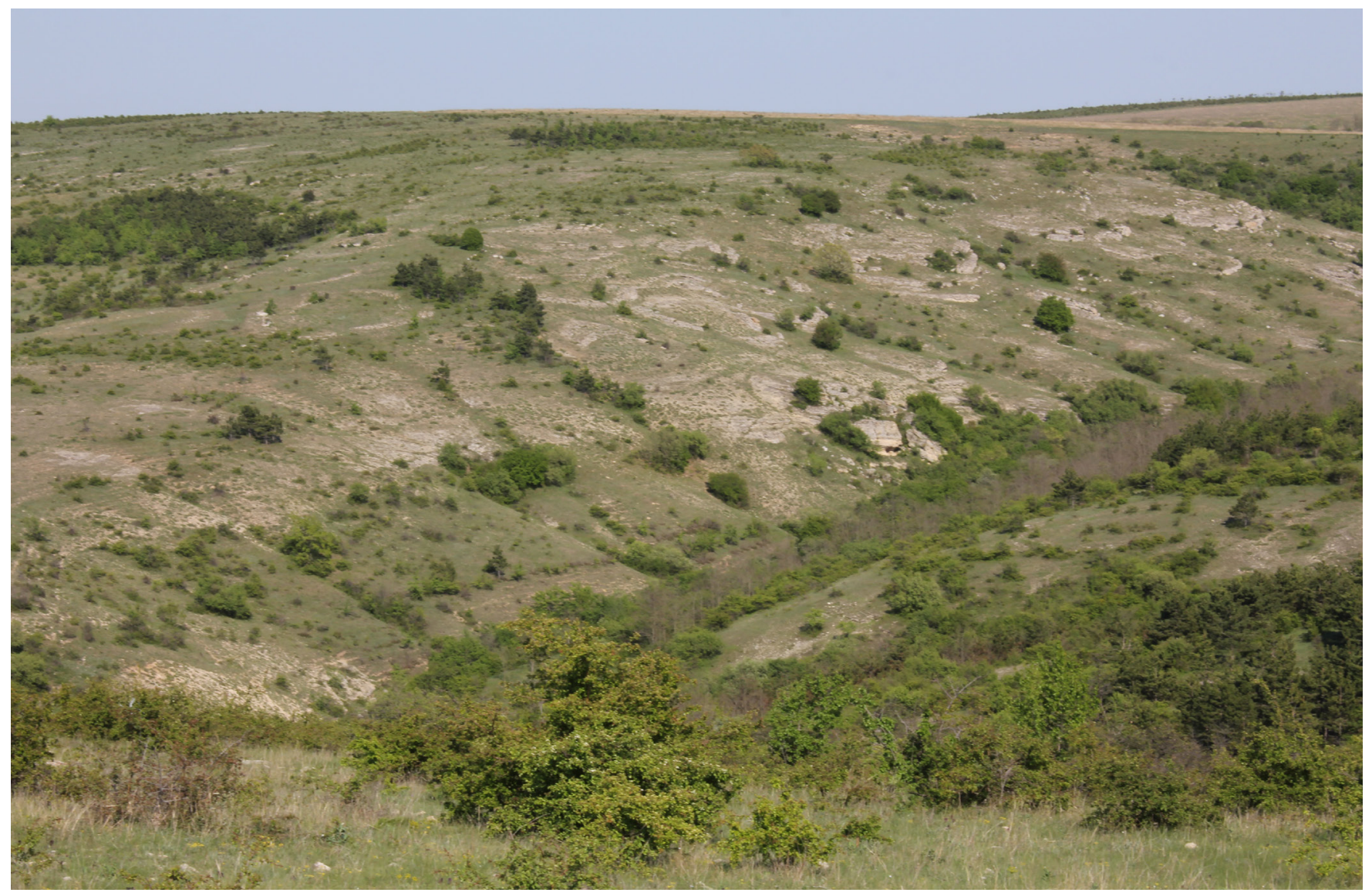

Fig. 5a. Habitat of R. bavius ssp. at Gura Dobrogei, Constanța County, 30.04 .2012 (Photo: L. Rákosy).

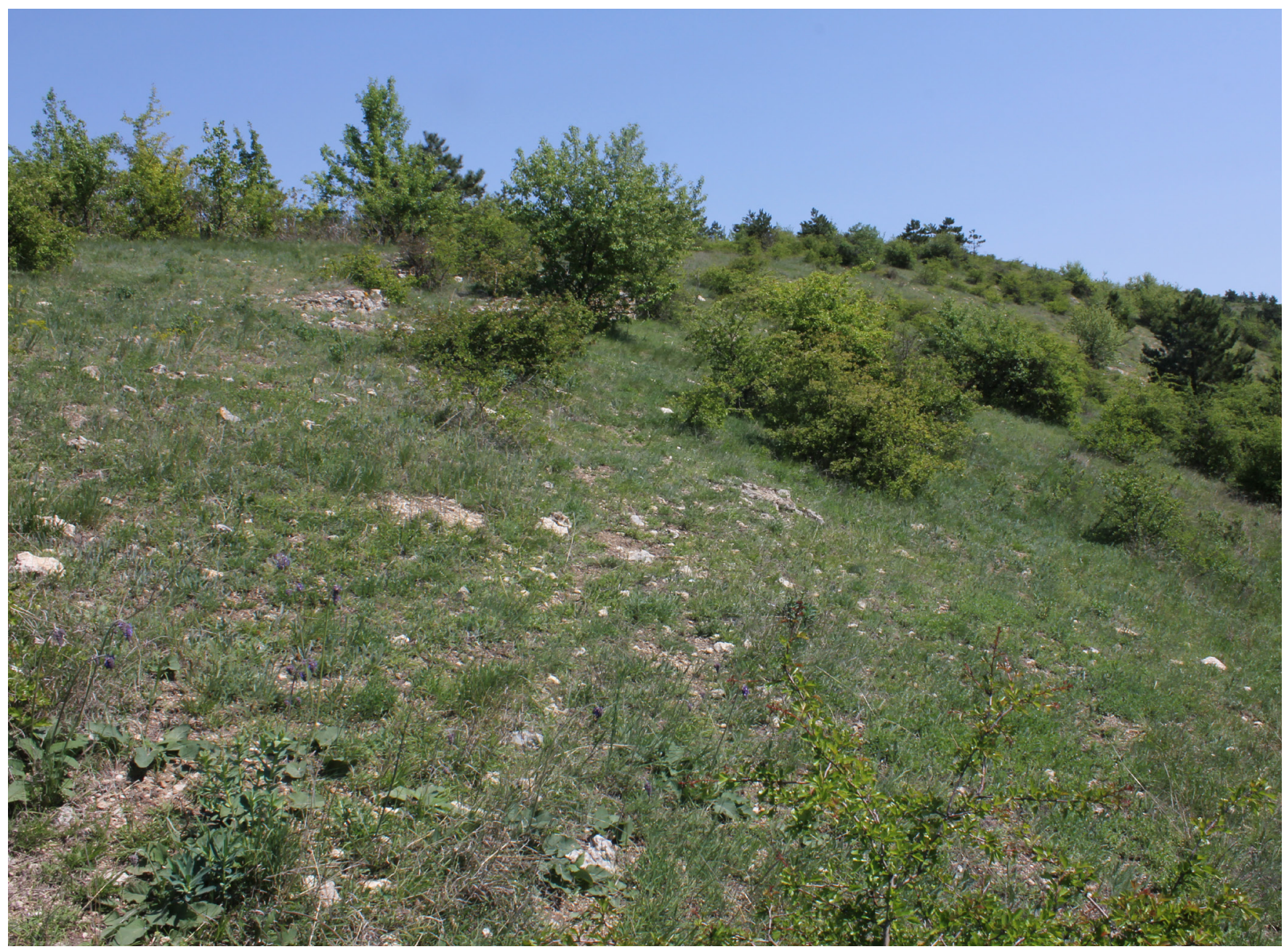

Fig. 5b. Habitat of R. bavius ssp. at Gura Dobrogei, Constanța County, 30.04 .2012 (Photo: L. Rákosy). 


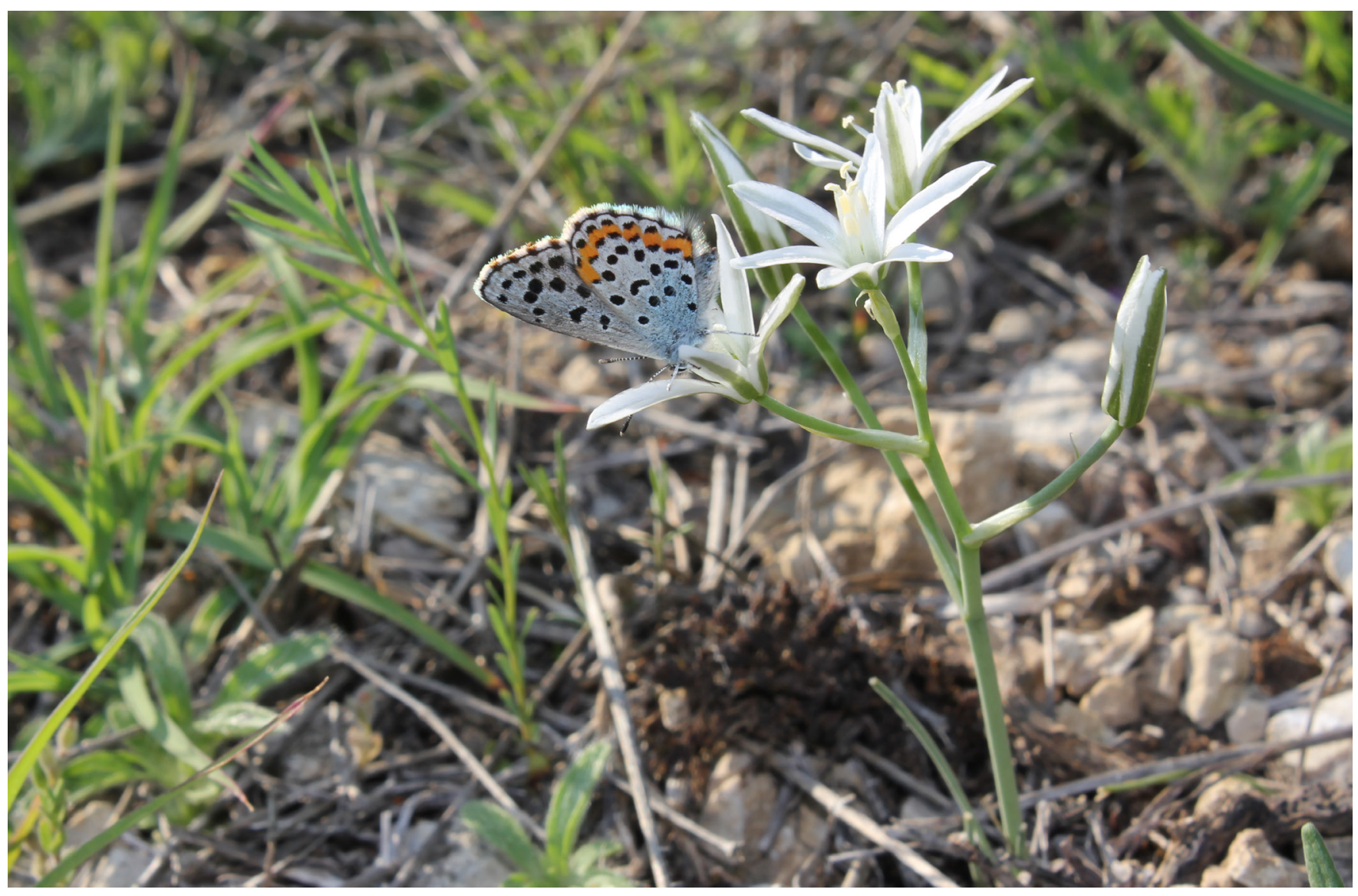

Fig. 6. Male of R.bavius ssp., Gura Dobrogei, Constanța County, 30.04.2012 (Photo: L. Rákosy)

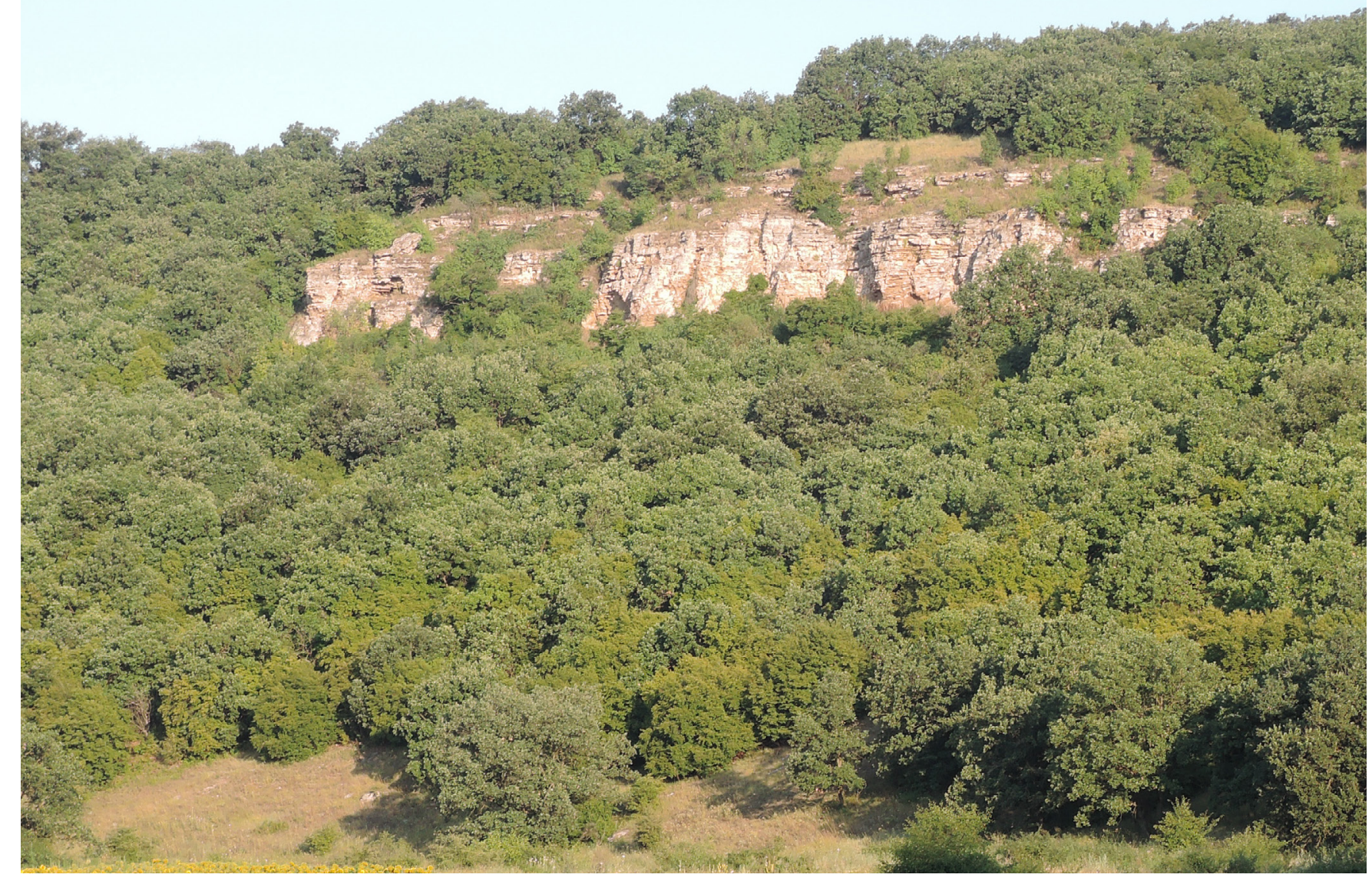

Fig. 7. Habitat of R. bavius ssp. at Șipote, Constanța County, 18.07.2015 (Photo: L. Rákosy) 


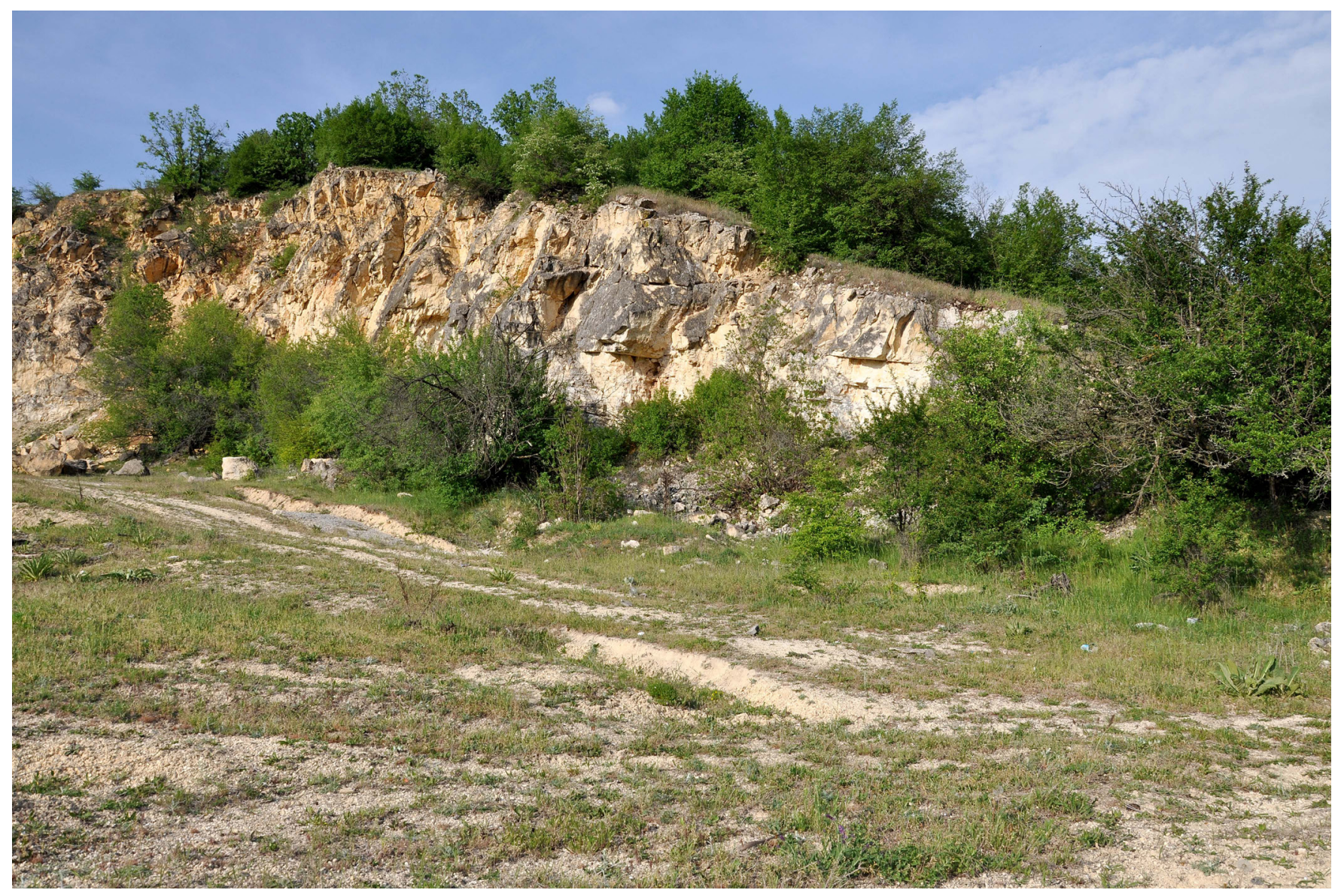

Fig. 8. Habitat of R. bavius ssp. from north-eastern Bulgaria, Balik, Silistra district, 4.05.2013 (Photo: M. Weidlich)

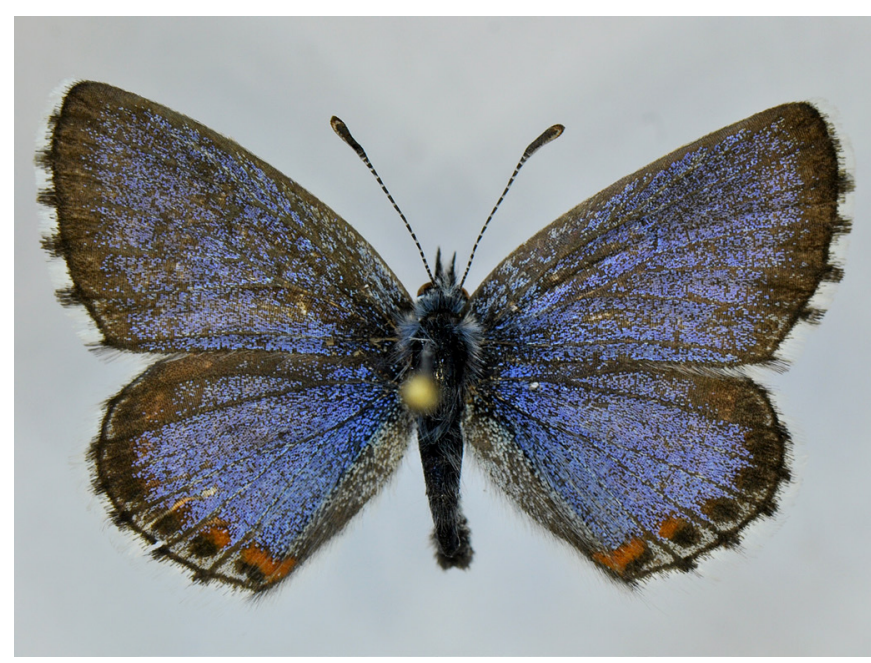

\section{Europa meridionalis}

Bulgaria septentrionalis $1 \mathrm{~km}$ SE Balik b. Dobritsch FFH "Suha reka" 04. Mai $2013 / 110 \mathrm{~m}$ leg. Dr. M. Weidlich

Fig. 9. Male (upperside) and the label of $R$. bavius ssp., Balik, Silistra district, 4.05.2013 leg. et coll. M. Weidlich (Photos: M. Weidlich)

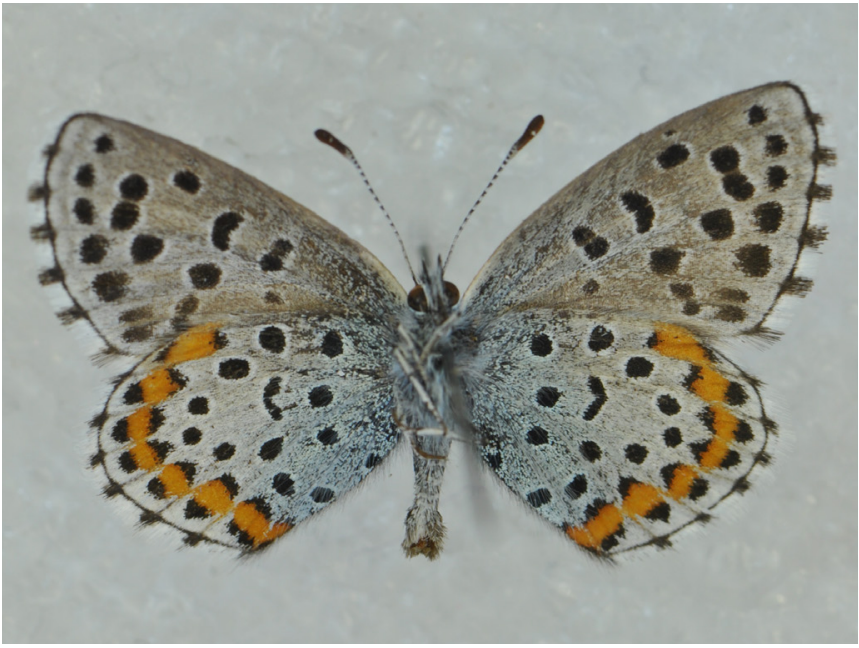

Fig. 10. Male (underside) of $R$. bavius ssp., Balik, Silistra district, 4.05.2013 leg. et coll. M. Weidlich (Photo: M. Weidlich)

the vicinity to the Turkish populations, let us believe that this Bulgarian population may be geographically isolated and genetically differentiated from the $R$. bavius populations from Dobrogea. This population lies closer to other R. bavius populations from Turkey, and most likely belongs to the ssp. egea (HASSELBARTH et al. 1995) (Fig. 1). Until a more detailed molecular analysis will be available, it remains unclear whether the populations from Dobrogea are more closely related to those from Turkey or to those from the Crimean Peninsula and southern Ukraine. The 
climatic conditions and the habitat described by Kolev suggest, however, that the populations from Dobrogea are different from those from south-eastern Bulgaria and Turkey.

Currently the phylogenetic relationships between the Transylvanian populations (ssp. hungarica) and those from Dobrogea (possibly an unknown subspecies), south-eastern Bulgaria (ssp. egea?), Greece and Macedonia (ssp. macedonica), western Turkey (ssp. egea) and other taxa from the Caucasus and Turkey are unknown. The morphological comparisons conducted by CouTsIs (2008) based on the male genital armature were only aimed at revealing among-species differences and are, in our opinion, not particularly relevant for comparisons at the subspecies level.

It seems, however, highly likely that the populations from north-eastern Bulgaria belong to the same taxon as those from the Romanian side of Dobrogea. If these populations are genetically identical with those from south-eastern Bulgaria and western Turkey and thus belong to ssp. egea remains to be seen. Preliminary data based on cytochrome $c$ oxidase subunit 1 (COI) sequences (DNA barcodes) of several individuals from Transylvania, Dobrogea, Ukraine, Greece and Macedonia indicate that the populations from Dobrogea represent distinct haplotypes, but relationships were not fully resolved, possibly due to limited DNA data (pers. com. DINCĂ 2017). Studies based on geometric morphometrics or nuclear genetic markers are currently missing, the phylogenetic relationships at the sub- and infraspecific level thus remaining speculative.

Although the species has not yet been discovered in northern Dobrogea, the presence of suitable habitats with $S$. nutans suggests that $R$. bavius could nevertheless occur in this region. Its potential presence in northern Dobrogea opens the possibility of a contact with the populations from south-eastern Ukraine and the Crimean Peninsula (Fig. 1). This further underlines the necessity of a comparative molecular study of the populations from Romania, the Balkans, Ukraine and western Turkey (Fig. 1). Other, yet undiscovered populations of $R$. bavius, could be found in southern Ukraine, southern Moldavia, the Balkans and Asia Minor.

\section{Conservation}

Rubrapterus bavius is a protected species listed in the annexes of the Council Directive 92/43/EEC on the conservation of natural habitats and of wild fauna and flora (II and IV), in the national legislation (OUG nr. 57/2007 approved with amendments by Law 49/2011 on the protected nature reserves, natural habitats, wild flora and fauna), and in the Red List of Romanian Lepidoptera (RÁKosy 2003, RÁKosY et al. 2003). Taking into account that the main European populations are found in Romania, Greece and Macedonia, we consider that the classification of this species into the "least concern" or "not evaluated" categories of the Red Data Book of European Butterflies (VAN SWAAY et al. 2010) and in NUMA et al. (2016) is inadequate. The opinion of VAN SWAAY et al. (2012) that within the EU 27 the species is probably more endangered than its threat category suggests, is probably accurate. In the Red List of Romanian butterflies (RÁKOSY 2003), R. bavius is considered as "endangered". This status is supported by numerous studies and multiannual observations on the Romanian populations (CRIŞAN et al. 2011, DINCĂ et al. 2011, NÉMET et al. 2016, RÁKosY 2013, SzÉKelY 2016). It should be also noted that $R$. bavius is considered a species under very high climatic change risk, as its climatic niche could be reduced by up to $85-95 \%$ in the coming years (SETTELE et al. 2008).

Although $R$. bavius is protected by law and most of the sites harbouring the strongest populations have been included in protected areas, protection is ensured only on paper. Often, the habitats are being grazed even during the blooming season of the larval host plant. This means that eggs and larvae are being eaten from the Salvia nutans inflorescences. Overgrazing remains one of the highest environmental threats to this species, even as local awareness to the problem is rising (mainly through mass media coverage of the effect of intensive grazing on protected areas).

The discovery of this species on the Bulgarian territory compels the local authorities and the Bulgarian entomologists to take adequate protection and conservation measures. The foremost task should be to perform a detailed analysis of the potential habitats in north-eastern Bulgaria in order to identify viable populations. These habitats then need to be included in protected areas (natural reserves) with a special management strategy for $R$. bavius.

\section{Aknowledgements}

We are grateful to Demetra Rákosy for the translation of the manuscript into English and for critical suggestions. We sincerely thank Dr. Vlad Dincă for his interesting comments and valuable suggestions.

\section{References}

Abadjiev S. and Beshkov S. (2007) Prime Butterfly Areas in Bulgaria. Pensoft, Sofia, 222 pp.

Coutsis G.J. (2008) Pseudophilotes bavius casimiri, the most differentiated subspecies of the $P$. bavius species-group. Pseudophilotes fatma, a distinct species (Lepidoptera: Lycaenidae, Scolitantiditi). Phegea 36 (4): 121-125.

Crişan A., Sitar C., Craioveanu C. and Rákosy L. (2011) The protected Transilvanian Blue (Pseudophilotes bavius hungarica): new information of the morphology and biology. Nota lepid. 34(2): 163-168.

Crişan A., Sitar C., Craioveanu C.M., Vizauer C-T. and RÁKosy L. (2014) Multianual population size estimates and mobility of the endemic Pseudophilotes 
bavius hungarica (Lepidoptera: Lycaenidae) from Transilvania (Romania). North-Western Journal of Zoology 10 (Supplement 1): 115-124.

DiNCĂ V. and VILA R. (2008) Improving the knowledge on Romanian Rhopalocera including the rediscovery of Polyommatus amandus (SCHNEIDER, 1792) and an application of DNA-based identification. Nota lepid. 31(1): 3-23.

Dincă V., Cuvelier S. and MølgaArd S.M. (2011) Distribution and conservation status of Pseudophilotes bavius (Lepidoptera: Lycaenidae) in Dobrogea (southeastern Romania). Phegea 39 (2): 59-67.

Hasselbarth G., Van Oorscholt H. and Wagner S. (1995) Die Tagfalter der Türkei. - Bocholt 1: 753 pp., 2: 758-1354, 3: $847 \mathrm{pp}$.

Jutzeler D., RÁKosy L. and DE Bross E. (1993) Observation et élevage de Pseudophilotes bavius (EvERSMANN, 1832) de environs de Cluj; distribution de cette espèce en Roumanie. Un nouvelle plante nourriciére de Colias alfacariensis (Ribbe, 1905). Bull. Soc. Ent. Mulhouse, Avril-Juin: 23-30.

Kolev Z. (2017) Rubrapterus bavius (Eversmann, 1832), a butterfly genus and species new to Bulgaria (Insecta, Lepidoptera, Lycaenidae). ZooNotes 114: 1- 4.

KöNIG F. (1988) Date morfologice, biologice și ecologice referitoare la Philotes bavius hungarica Diószeghy, 1913 (Lepidoptera, Lycaenidae) In: a IV-a Conf. Nat. ent. Cluj-Napoca, 29-31 mai 1986: 175-182.

KöNIG F. (1992) Morphologische, biologische und ökologische Daten über Philotes bavius hungarica DiószeGHY, 1913 (Lepidoptera, Lycaenidae). Entomol. Zeitschrift, Essen 103 (18): 325-340.

Német E., Czekes Z., Markó B. and RÁkosy L. (2016) Host plant preference in the protected myrmecophilous Transylvanian Blue (Pseudophilotes bavius hungarica) butterfly (Lepidoptera: Lycaenidae) and its relationship with potential ant partners. Journal of Insect Conservation. DOI 10.1007/s10841-016-9907-5.

Numa C., van SwaAy C., Wynhoff I., Wiemers M., Barrios V., Allen D., Sayer C., Munguira M.L., Balletto E., Benyamini D., Beshkov S., Bonelli S., Caruana R., Dapporto L., Franeta F., GarciaPereira P., Karaçetin E., Katbeh-Bader A., Maes D., Micevski N., Miller R., Monteiro E., Moulai R., Nieto A., PAmperis L., Pe’er G., Power A., ŠAšić M., Thompson K., Tzirkalli E., Verovnik R., Warren M. and Welch H. (2016) The status and distribution of Mediterranean butterflies. IUCN, Malaga, Spain. x $+32 \mathrm{pp}$.

PAMPERIS L.N. (2009) The Butterflies of Greece. Ed. 2. Nature, Athens, $766 \mathrm{pp}$.

RÁKosy L. (1983) Problema ocrotirii lepidopterelor în România, exemplificări din județul Cluj. Ocrot. Nat. Med. Inconj. București 27 (1): 32-36.

RÁKosy L. (1998a) Die endemischen Lepidopteren Rumäniens (Insecta: Lepidoptera). Stapfia, Linz 55: 257-280.

Rákosy L. (1998b) Protecția naturii în România dintr-o perspectivă entomologică. Stud. cerc. Șt. nat., Bistriţa, 4: $285-290$.

RáKosy L. (2003) Lista roșie pentru fluturii diurni din România. Bul. Inf. Soc. lepid. rom.13 (1-4): 9-26.

Rákosy L. (2013) Fluturii diurni din România. Cunoaștere, protecție, conservare. Ed. Mega, Cluj-Napoca, 352 pp.

RÁKosy L. and SzÉKely L. (1996) Macrolepidopterele din sudul Dobrogei. Entomol. rom. 1: 17-62.

RÁkosy L., GoIA M. and Kovács Z. (2003) Catalogul Lepidopterelor României / Verzeichnis der Schmetterlinge Rumäniens. - Societatea Lepidopterologică Romană, Cluj-Napoca, 446 pp.

Settele J., Kudrna O., Harpke A., Kühn I., van SwaAy C., Verovnik R., Warren M., Wiemers M., Hanspach J., Hickler T., Kühn E., van Halder I., Veling K., Vliegenthart A., Wynhoff I. and Schweiger O. (2008) Climatic Risk Atlas of European Butterflies. Biorisk - Biodiversity and Ecosystem Risk Assessment 1, Pensoft Sofia - Moscow, 710 pp.

Szabó A. (1982) Contribuții privind răspândirea în România a speciilor Lycaena helle Schiff și Philotes bavius Ev. (Lepidoptera, Lycaenidae). Soc. S,t. Biol. R.S.R. Stud. com. Reghin, 2: 299-306.

SzÉKELY L. (1994) Des nouveautés concernant la faune de lépidoptères de sud-ouest de la Dobroudja. Sargetia. Series Sc. Nat. Deva, 14: 139-144.

SzÉKELY L., DinCĂ V. and JuHÁSZ I. (2011) Macrolepidoptera from the steppes of Dobrogea (southeastern Romania). Phegea, 39 (3): 85-106.

SzÉKELY L. (2016) New and rare Macrolepidoptera (Insecta) from Romanian Dobrogea (South-East Romania). Travaux du Muséum National d'Hist. Nat. “Grigore Antipa” 59(2): 195-230.

Tshikolovets V.V. (2011) Butterflies of Europe \& the Mediterranean area. Tshikolovets Publications, Pardubice, $544 \mathrm{pp}$.

Ugelvig L., Vila R., Pierce N. and Nash D. (2011) A phylogenetic revision of the Glaucopsyche section (Lepidoptera: Lycaenidae), with special focus on the Phengaris-Maculinea clade. Molecular Phylogenetics and Evolution, 61: 237-243.

van Swayy C., Cuttelod A., Collins S., Maes D., Munguira M.L, ŠAšić M., Settele J., Verovnik R., Verstrael T., Warren M., Wiemers M. and WynhofF I. (2010) European Red List of Butterflies. Publications Office of the European Union, Luxembourg. viii + 46pp.

van Swaay C., Collins S., Dušej G., Maes D., Munguira M.L., Rákosy L., Ryrholm N., ŠAšić M., SetTele J., Thomas J.A., VerovniK R., Verstrael T., Warren M., Wiemers M. and Wynhoff I. (2012) Dos and Don'ts for butterflies of the Habitat Directive of the European Union. Nature Conservation, 1: 73-153.

VICOL V. (1983) Philotes bavius Ev. în fauna de Lycaenidae (Lepidoptera, Rhopalocera) a Transilvaniei. Considerații sistematice, biologice și zoogeografice. Marisia, Târgu Mureș 11-12:125-129.
László Rákosy

Department of Taxonomy and Ecology

"Babeș-Bolyai" University,

Clinicilor 5-7, Cluj-Napoca,

Cluj, Romania

E-mail: laszlo.rakosy@ubbcluj.ro
Michael WeIDLICH

Lindenallee 11

15898 Neißemünde OT Ratzdorf

Germany

E-mail:dr.michael.weidlich@gmail.com
Received: 22.11 .2017

Accepted: 30.11.2017

Published online: 28.12.2017

Published: 28.12.2017

Online article number: ER21201703

doi: 10.24193/entomolrom.21.3 